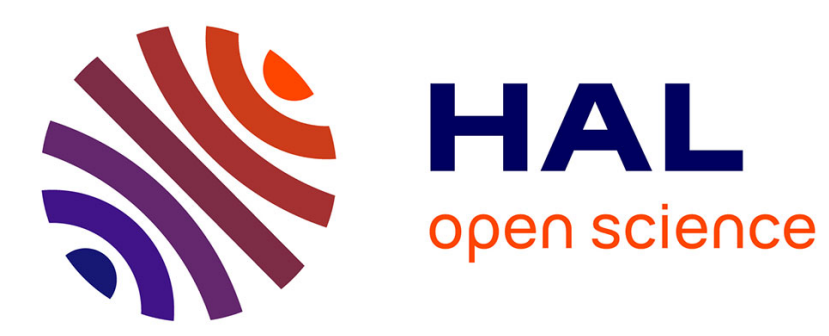

\title{
Reasoning processes in prehistoric art interpretation
}

\author{
Sophie A. de Beaune
}

\section{To cite this version:}

Sophie A. de Beaune. Reasoning processes in prehistoric art interpretation. Primitiva Bueno-Ramírez; Paul G. Bahn. Prehistoric Art as Prehistoric Culture Studies in Honour of Professor Rodrigo de Balbín-Behrmann, Archaeopress Archaeology, p. 25-29, 2015. halshs-02063042

\section{HAL Id: halshs-02063042 https://shs.hal.science/halshs-02063042}

Submitted on 10 Mar 2019

HAL is a multi-disciplinary open access archive for the deposit and dissemination of scientific research documents, whether they are published or not. The documents may come from teaching and research institutions in France or abroad, or from public or private research centers.
L'archive ouverte pluridisciplinaire HAL, est destinée au dépôt et à la diffusion de documents scientifiques de niveau recherche, publiés ou non, émanant des établissements d'enseignement et de recherche français ou étrangers, des laboratoires publics ou privés. 


\title{
PREHISTORIC ART AS PREHISTORIC CULTURE \\ STUDIES IN HONOUR OF PROFESSOR RODRIGO DE BALBÍN-BEHRMANN
}

\author{
edited by \\ Primitiva Bueno-Ramírez \\ and Paul G. Bahn
}




\section{ARCHAEOPRESS PUBLISHING LTD \\ Gordon House \\ 276 Banbury Road \\ Oxford OX2 7ED}

www.archaeopress.com

ISBN 9781784912222

ISBN 9781784912239 (e-Pdf)

(C) Archaeopress and the individual authors 2015

Cover: "Galería de los Antropomorfos" Tito Bustillo cave, Asturias, Spain.

Photos by Rodrigo de Balbín

All rights reserved. No part of this book may be reproduced, stored in retrieval system,

or transmitted, in any form or by any means, electronic, mechanical, photocopying or otherwise, without the prior written permission of the copyright owners.

Printed in England by Oxuniprint, Oxford

This book is available direct from Archaeopress or from our website www.archaeopress.com 


\section{Contents}

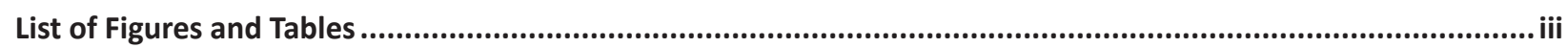

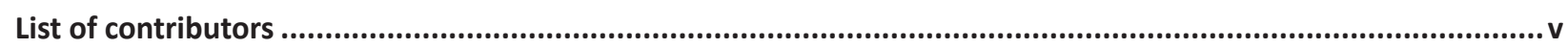

Prehistoric Art as Prehistoric Culture .............................................................................................. vii

Primitiva Bueno-Ramírez and Paul Bahn

'Science' versus Archaeology: Palaeolithic Rock Art at the beginning of the 21st century...................................1

José-Javier Alcolea-González and César González-Sainz

Raman spectroscopy of prehistoric pictorial materials

Antonio Hernanz

Prehistoric rock art and non-invasive analysis. Rouffignac as a case study

Patrick Paillet

Reasoning processes in prehistoric art interpretation

Sophie A. de Beaune

Are hand stencils in European cave art older than we think? An evaluation of the existing data and their potential implications.

Paul Pettitt, Pablo Arias, Marcos García-Diez, Dirk Hoffmann, Alfredo Maximiano Castillejo,

Roberto Ontañon-Peredo, Alistair Pike and João Zilhão

Regional ontologies in the Early Upper Palaeolithic: the place of mammoth and cave lion in the 'belief world' (Glaubenswelt) of the Swabian Aurignacian

Shumon T. Hussain and Harald Floss

Aurignacian art in the caves and rock-shelters of Aquitaine (France)

Brigitte and Gilles Delluc

Fuente del Trucho, Huesca (Spain): Reading interaction in Palaeolithic art

Pilar Utrilla and Manuel Bea

Open-air Ice Age art: the history and reluctant acceptance of an unexpected phenomenon

Paul G. Bahn

Decorated sites and habitat: social appropriation of territories

Denis Vialou

Deep caves, ritual and graphic expression: a critical review of the archaeological evidence on hypogean human activity during the Upper Palaeolithic/Magdalenian.

Pablo Arias

Magdalenian settlement-subsistence systems in Cantabrian Spain: contributions from El Mirón Cave 111

Lawrence G. Straus, Manuel González Morales, Ana B. Marín-Arroyo and Lisa M. Fontes

The Upper Palaeolithic rock art of Portugal in its Iberian context. 123

André Tomás Santos, Maria de Jesus Sanches and Joana Castro Teixeira 
Old panels and new readings. La Pileta and pre-Solutrean graphics in Southern Iberia

Miguel Cortés Sánchez, María D. Simón Vallejo, Rubén Parrilla Giráldez, and Lydia Calle Román

Palaeolithic art in the Iberian Mediterranean region. Characteristics and territorial variation

Valentín Villaverde

Small seeds for big debates: Past and present contributions to Palaeoart studies from North-eastern Iberia ... José María Fullola, Ines Domingo, Didac Román, María Pilar García-Argüelles, Marcos García-Díez and Jorge Nadal

Throwing light on the hidden corners. New data on Palaeolithic art from NW Iberia 171 Ramón Fábregas Valcarce, Arturo de Lombera-Hermida, Ramón Viñas Vallverdú, Xose Pedro Rodríguez-Álvarez, and Sofia Soares Figueiredo 


\title{
Reasoning processes in prehistoric art interpretation
}

\author{
Sophie A. de Beaune \\ Jean Moulin University, Lyon / ‘Archéologies et Sciences de l’Antiquité’ Research Unit, Nanterre
}

I have no data yet. It is a capital mistake to theorise before one has data. Insensibly one begins to twist facts to suit theories, instead of theories to suit facts.

A. Conan Doyle, A Scandal in Bohemia, The Adventures of Sherlock Holmes, 1891.

\begin{abstract}
Since the 19th century, the authors of suggested explanations to figure out prehistoric art have tried to convince the scientific community of the legitimacy of their interpretation. To these ends, they have resorted to different types of reasoning deduction, induction and abduction - that we analyse here on the basis of some famous examples. We will see how the intellectual approach has changed since the beginning of prehistoric archaeology, although the reasoning modes have remained the same.

Résumé Les modes de raisonnement en jeu dans l'interprétation de l'art préhistorique Depuis le xixe siècle, les auteurs des explications proposées pour cerner l'art préhistorique ont essayé de convaincre la communauté scientifique du bien-fondé de leur interprétation. Pour ce faire, ils ont eu recours à différents types de raisonnement - la déduction, l'induction et l'abduction - que nous analysons ici à partir de quelques exemples fameux. Nous verrons en quoi la démarche intellectuelle a changé depuis les débuts de la préhistoire, même si les types de raisonnement sont eux restés les mêmes.
\end{abstract}

The various interpretations that have been made for more than a century in prehistory in general, and more specifically in parietal art, were influenced by the intellectual environment in which their authors were immersed. Thus, the theory of art for art 's sake, supported by Gabriel de Mortillet, represented the anti-religious and anticlerical wave from the end of the 19th century. It then became tempting to link together all magical-religious interpretations to what we thought we knew of the 'primitive' populations that were starting to be studied, and to the works of LévyBruhl concerning primitive mentality, of Durkheim concerning elementary forms of religious life , and of Frazer who in 1887 came up with the very fashionable idea of totemism. More recently, Clottes and LewisWilliams were influenced, consciously or not, by the neo-shamanism movement that was very trendy in the USA in the 1990s.

I will not study their assumptions themselves, which have nowadays been hit by the transience to which all our productions are doomed. I will rather take interest in the arguments of their authors. For as dependent as they were on the ideas of their time, they nevertheless went through the effort of suggesting types of reasoning worthy of being looked into. My work will therefore be applied to a specific case: a reflection on the reasoning style at work in prehistory.

\section{Reasoning in prehistory}

A word first about the two types of reasoning from which a prehistorian - like his colleagues in other subjects cannot be exempt: deduction and induction.
The first consists of starting from a general assertion in order to infer a specific one. Socrates is a man, men are mortal, therefore etc. In Prehistory, an example of deduction would consist of saying: 'if I found numerous scrapers in this site and if scrapers were used to prepare skins, then skins have been prepared in this site.' Or 'if I found numerous cores and flint debris in a specific area of a site and if these elements were produced during flint knapping, then it is a flint workshop area.'

The second, on the other hand, consists of assuming that a specific phenomenon illustrates a more general law. It naturally has hypothetical characteristics and must be handled with tact, its purpose being to be able to feel whether the risk taken can lead to any heuristics. 'Induction reasoning occurs when having put forward a property of one or few individuals of a same class of beings or events, one considers that all other individuals of this class show the same property'. The accumulation of corroborative facts as well as the absence of counterexamples enable the law's plausibility level to increase until one decides to consider it a near-certainty. Therefore, the repetition of a phenomenon is what increases the likelihood of it happening again. That is how Marcel Otte considers that prehistoric men had a religion, for there is no such thing as a people without religion. Another example would be the fact that all gallery graves that were not in acid soil have yielded human bones, making it plausible for those gallery graves to be funerary monuments, even when no human remains are found, due to a lack of good preservation conditions. Results from an induction are nevertheless tenuous, since the unexpected appearance of a counterexample is enough to make them invalid. 
A third type of reasoning, abduction, needs to be added. It consists of going from a clue to a hypothesis, or even from a piece of data to a theory. This type of reasoning starts with the principle that to a given effect, a corresponding cause can be found. It makes it possible to go back from the trace to the fact, as Zadig does in Voltaire's tale: confronted by a few traces, uncertain clues, he proves himself able to describe Babylon's sovereigns' dog and horse, although he saw neither one nor the other. Zadig carries out deductions as well as inductions, for he must establish a general hypothesis concerning dogs' and horses' behaviour. But he applies them less to proposals ('Socrates is a man') than to clues, from which he imagines a scenario that his experience and his acute use of induction and deduction make plausible.

Moreover, Arthur Koestler speaks of reasoning in reverse with regard to this process. It is also more the detective's method - it was popularized by Conan Doyle with his hero, Sherlock Holmes - than that of the prehistorian. It must be said that what the prehistorian has in common with the detective - and with Zadig - is that he is in the presence of traces, often unintentional, and that he must, from those, imagine something about the men who left them behind.

The most famous examples in prehistory may be those of Lewis Binford and André Leroi-Gourhan, who attempted to infer the organisation of habitation structures from analysis of the spatial distribution of remains on the ground. The episode that remained famous amongst Camp Millie's prehistorians shows just how delicate this type of reasoning can be.

In actual fact, every scientific construction (as well as every police investigation) is made up of abduction, induction and deduction. But one has to admit that the scientific approach is essentially abductive. Whether in 'hard' sciences or in human sciences, the researcher offers from what he observes - and what he observes is often reduced to very little - an explanatory principle that is as plausible as possible.

\section{Modes of reasoning in prehistoric art}

Let us now see what occurs in the study of cave art. Without going through an exhaustive historical background of all the explanatory hypotheses suggested for more than a century, let us examine on what type of reasoning the most famous were based.

Before the recognition of the Palaeolithic age of this art, these manifestations were believed to be attributable to shepherds from the Middle Ages, on the grounds that prehistoric men were unable to achieve such art. One could question the reasoning that led most archaeologists of these times to deny that artistic manifestations were of prehistoric age. We know that Don Marcelino Sanz de Sautuola did not succeed in convincing others of the antiquity of the polychrome paintings on Altamira's ceiling, and that he was even accused of forgery. The general idea was that man necessarily went through gradual evolutionary stages and that, consequently, Renaissance art was necessarily superior to that of Prehistoric men. Following the classification of societies by Lewis Morgan in Ancient Society in 1877, we could identify six stages - the three lower stages of 'savagery' and the three upper stages of 'barbarism' — through which human societies had to pass before reaching, for some of them, the seventh stage: civilization. As newly discovered 'primitive' societies, prehistoric societies were placed in the savagery stage, and it was thus unconceivable to connect them to an art as technically and stylistically evolved as the one we could observe at the stage of civilization. That was a deductive reasoning, although based on false premises.

When it became necessary to submit to the obvious, and admit that certain objects' decorations were made by prehistoric men contemporary with extinct animal species, a similar argument was used to explain this art: it was an art searching no reward, recreational, for these people were still unable to develop any religious feeling. It was the theory of art for art's sake. According to Moro Abadia and González Morales, it was difficult to deny the aesthetic character of these objects, but at the same time one could not consider their authors as real artists. As a result, they were interpreted as solely decorative manifestations, assimilating them to decorative art and opposing them to major art forms or fine arts. Here again deduction was used, although it was not formally clarified. But this hypothesis was also based on induction since parietal art was considered a result of an artistic need common to all humanity.

Once the antiquity of cave art was definitely accepted, several concurrent hypotheses were developed at the same time. Let us briefly focus on the one concerning prehistoric totemism. Expressed since the end of the 19th century, this hypothesis was promoted by Salomon Reinach, under the strong influence of the work of Baldwin Spencer and Francis Gillen, published in 1899, concerning Australian Aborigines. These authors wrote that, according to their totemic religion, Australians made cave paintings during grand ceremonies that gathered the community together regularly. Totemism, then considered the most archaic form of religion, was seen as the cult of a sacred animal that every clan worshipped and used as a rallying symbol for its members. The animals represented in caves — bison, horse, rhinoceros... would have represented totems of different prehistoric clans. We can see here that besides very frequently resorting to analogy at that time, Salomon Reinach tried to apply abduction based on animal representation. This theory was nevertheless quickly abandoned, because 
since these animals were found in all the caves, it was impossible to precisely delineate the clans. Furthermore, the fact that some animals are outlined with strokes goes against this hypothesis: a totemic animal cannot be both game and worshipped ancestor at the same time.

Another explanatory hypothesis, which largely replaced the others during the first half of the 20th century, was that concerning the magic of hunting and bewitchment, notably defended by Salomon Reinach and the abbé Breuil and regularly maintained with a few variables in the 1970s. It was based on the idea that the production of an animal representation on cave walls was supposed to encourage game multiplication, to ensure the success of the coming hunt, to keep danger away, or to seek the animal's forgiveness and consent before its sacrifice. During those 'magical' or 'magico-religious' rites, animals would have been symbolically killed on the wall. We could see here an implicit deduction starting with the premise that the represented animals were exclusively those that this hunting people ate. Salomon Reinach, one of the first to support this hypothesis, was on the other hand quite dishonest, for he claimed that other represented animals, those that were not game, like hyenas or snakes, were misinterpreted. Later on, this hypothesis was reinforced by the discovery of other caves in which strokes that could be interpreted as arrows or assegais were represented. The geometrical signs were also interpreted by some, like Henri Bégouën, as representations of traps.

This hypothesis was based on the methodological principle stated by Georges-Henri Luquet in 1931: 'a human action whose motive is unknown by us can have been produced by the same motive that we know to have produced the same action in other circumstances, and this possibility is all the more likely from the same actions and the same motives meeting each other in numerous and various environments.' Which means that the same causes produce the same effects, and that if we know what actions led to the representation of certain patterns elsewhere, we can deduce what patterns were uppermost in the representation of prehistoric patterns. This is a deduction, but an induction as well, since we go from particular to general. And finally it is also an abduction, since all these theories are built on the representations themselves, which are supposed to prove these magical doings. Thus the representations themselves were seen as proof of these practices: the represented animals were the animals hunted for their meat - bison and horses - but also because they were dangerous, which could explain the representations of felines or bears. The absence of animals such as reindeer or salmon that were nevertheless on these Palaeolithic hunters' menu - was explained by the fact that this game, very abundant and quite stupid, did not need any specific magic, being so easy to catch. Moreover, the destruction and the superimposition of numerous figures proved that only the making of the works mattered, and that it was done during magical rites, the result being after all of lesser importance. The presence of hands and sexual representations were the reflection of rituals related to fertility, as a usual complement of hunting magic, meant to facilitate the multiplication and abundance of game.

At least four arguments were put forward to reject the hunting magic hypothesis: the animal species represented on the walls are not those that were hunted, as proved by the presence of their bones in habitation sites; the signs that were interpreted as throwing weapons only concerned a small proportion of animals; some of these alleged weapons were drawn on the wall before the animal they were supposed to symbolically kill; and lastly, this hypothesis does not account for the existence of many abstract figures. We see that the opponents to this hypothesis also largely resorted to abduction, since they noted that, in order to justify the hypothesis, there is a lack of evidence which could enable one to go from traces to facts. Or, in other words, they pointed out the mistake of their opponents' abduction.

In the 1960s, Leroi-Gourhan analysed the relationship between the figures and their distribution in the inner space of the cave. He looked for recurring elements that could highlight the caves' systematic structuring. This approach was qualified as 'structuralist' — even though Leroi-Gourhan always refused to use the term - since it focused more on the layout — the 'structure' — of the elements that make up a cave's decoration, than on the elements themselves. He then practised induction, trying to pass from specifics to the general in order to identify general laws, invariants. He believed that there existed an identical structure in all the FrancoCantabrian area's decorated caves. That was probably the weakness in his analysis, although the idea that figures are not randomly placed and that we have to try to understand the connections between them as well as with the cavities' inner topography was nevertheless a definite and innovative contribution. If the existence of a preconceived ideal plan that could be applied to all caves has proved false, or subsequently at least unprovable, it is now widely acknowledged that the cave decorations were not done randomly, and that there really is an internal cave organization, possibly regionally speaking. We can also note that he did not use abduction: indeed he was not trying to build a plausible scenario that would help to explain the clues around him, he was simply trying to see how these clues fitted together. Induction came next, when he assumed that the arrangements he brought to light were the illustration of a general law.

At the end of the 20th century, Jean Clottes and David Lewis-Williams attempted to prove that parietal art had been produced by shamans who represented on the cave walls the visions they had access to while in trance, either during or after seeing the visions. Their first 
hypothesis was based on the fact that, according to one of them, a link could be drawn with Southern African Bushman art, which was supposedly the work of shamans who came to draw their visions. By reasoning through deduction, these authors were putting together a dangerous syllogism: trance is universal, shamans go into trance, so prehistoric people were shamans. There has been a great deal of criticism of this hypothesis, and this is not the place to revisit the matter. We can bear in mind that their deduction is wrong on several points. They maintain that trance is universal and that it goes through several stages, which are also universal. However, no neurologist confirms the existence of such universal stages of trance. Moreover, it is known that Siberian shamans often only simulate trance. Conversely, trance is to be found in many practices, not necessarily ritual or religious, such as in dance. In other words, trance is neither 'necessary nor sufficient' to characterize shamanism.

In order to reach their goal, they also used abduction, as they had to build up scenarios, imagine shamans going through their rituals and drawing their visions on the wall: from their point of view, incomplete animal figures reveal the shaman's will to represent animals coming out of the wall, that is to say, going from one world to another. They also returned to the old hypothesis concerning the (very rare) figures of therianthropic half-human half-animal beings, who were themselves shamans at a certain point of the trance. Let us merely specify that, if one had to take this to its logical conclusion, one would have to call upon shamanism every time one was faced with an art using geometrical patterns as well as partly human and partly bestial representations. So there would have to be Greek shamanism, shamanism in Roman art, etc. It shows here that their abductive reasoning lacks plausibility, for it is obvious that the - in this case incomplete - animal figurations can be explained by other causes then those they call upon.

\section{In conclusion}

Whatever their interpretation, prehistorians search walls for traces of their assertions, as a manifestation of the evidence they submit. In doing so, they all apply abduction with varying degrees of success. What Breuil searched for in figures was the proof that thrown weapons were used to symbolically kill animals on walls; Clottes looked for proof of shamanism in incomplete figures and therianthropic beings. This can seem obvious, as a prehistorian has no other option than to start from remains. He can only start with the trace in order to understand its origin. The only one not to have used abduction, as I have said, is Leroi-Gourhan: he did not go from clues to something else, he stayed at the stage of clues. The approach is specific, and it is probably why it was the most fertile as far as heuristics are concerned.
Even among those who use abduction, approaches can be very different from one another. One consists of starting from a fully made model, and then applying archeological data to it. It is the approach followed by all the first prehistorians, from Salomon Reinach to René Nougier in the 1970s, who had in mind one or several models borrowed from ethnology - totemism, hunting magic, bewitchment... - and who tried to insert their observations into those models. They were all trying to include data in prior explanatory settings: beyond the figures themselves, there were other archaeological clues such as footprints, etc, that had to fit the mould. They freely dipped into travellers' stories and the first ethnographic monographs in order to find suitable examples. This approach, consisting of integrating these traces into a pre-established model, can be called top-down. It is not used much nowadays, at least in the artistic field, although Clottes' and Lewis-Williams' approach was close to it, even though they denied it. Several prehistorians recently rose up against the practice of starting from a model, especially in the social field, concerning the classification of societies.

The opposite approach consists of starting with the archaeological data themselves in order to try and find their meaning. It is nowadays the most common approach. It is for instance the case of Rodrigo de Balbín Behrmann when he tries to bring to light a 'geography' of art in the Sella valley from detailed examination of the depicted themes. It is also Randall White's case when he looks at the skills involved in the making of adornments that can — incidentally — tell us something about the society's organization and the interaction between different human groups. Leroi-Gourhan's approach, regardless of its specificity, is also similar, and can be called bottom-up.

Even if the archaeological clues are always used as validation of evidence, one can see that there is obviously an evolution in the type of reasoning that is practised. Nowadays, no one practises prehistory as they did at the turn of the 20th century, by trying to stick what we thought we knew about 'savage' peoples onto prehistoric men, and this is not only a question of the analytical means to which researchers have access. If reasonings - induction, deduction, abduction - have not changed, simply because we do not have an infinite number of them at our disposal, the approach is now globally more cautious, more reasonable: we are no longer looking for grand explanations with universal validity, which probably reflects a more humble attitude on the part of researchers.

\section{References}

Balbín Behrmann, R. de 2014. Los caminos más antiguos de la imagen: el Sella, pp. 65-91 in (R. de 
Balbín Berhmann et al., eds) Expresión simbólica y territorial: los cursos fluviales y el arte paleolítico en Asturias. Real Instituto de Estudios Asturianos: Oviedo.

Beaune, S. A. de 1999. [1995] Les Hommes au temps de Lascaux. 40000 - 10000 avant J.C.. Hachette, La Vie Quotidienne: Paris.

Beaune, S. A. de 2016. Qu'est-ce que la préhistoire? Gallimard, Folio Histoire : Paris.

Bégouën, H. 1939. Les bases magiques de l'art préhistorique. Scientia LXV (CCCXXIV), série IV, vol. XXXII: 206-16.

Bégouën, H. 1943. De la mentalité spiritualiste des premiers hommes. Académie des Jeux floraux, Toulouse, 27 novembre 1942. Douladoure Frères : Toulouse.

Bonnichsen, R. 1973. Millie's camp: An experiment in archaeology. World Archaeology 4 (3): 277-91.

Breuil, H. 1952. Quatre cent siècles d'art pariétal, les cavernes ornées de l'Âge du Renne. Centre d'Etudes et de Documentation Préhistoriques : Montiognac.

Butterlin, P. 2012. Archéologie et sociologie: le cas de l'Orient ancien, pp. 184-93 in (S. A. de Beaune \& Henri-Paul Francfort, eds) L'Archéologie à Découvert. CNRS Éditions: Paris.

Clottes, J. \& Lewis-Williams, D. 1996. Les Chamanes de la Préhistoire. Transe et magie dans les grottes ornées. Le Seuil: Paris.

Denis, G. 2008. L'analogie dans les sciences du végétal : à propos des positions de F. Fontana et d'A.-P. de Candolle sur les maladies des plantes, pp. 237-81 in (M,-J. Durand-Richard et al., eds) L'analogie dans la démarche scientifique. Perspective historique. L'Harmattan: Paris.

Groenen, M. 1994. Pour une histoire de la préhistoire. Le Paléolithique. Jérôme Millon: Grenoble.

Hamayon, R. 1995. Pour en finir avec l'extase et la transe dans l'étude du chamanisme. Études mongoles et sibériennes 26: 155-90.

Helvenston, P. A. \& Bahn, P. G. 2002. Desperately seeking Trance Plants: Testing the 'Three Stages of Trance' model. RJ communications LLC: New York.

Koestler, A. 1964. The Act of Creation. Hutchinson \& Co.: London.

Laming-Emperaire, A. 1962. La Signification de l'Art Rupestre Paléolithique. Picard: Paris.

Leroi-Gourhan, A. 1965. Préhistoire de l'Art Occidental. Lucien Mazenod: Paris.

Lorblanchet, M. et al. (eds) 2006. Chamanisme et Arts Préhistoriques. Vision critique. Errance: Paris.

Luquet, G.-H. 1931. La magie dans l'art paléolithique. Journal de Psychologie normale et pathologique $28^{\mathrm{e}}$ année: 390-427.

Mainage, T. 1921. Les Religions de la Préhistoire. L'Âge Paléolithique. Desclée de Brouwer: Paris.

Moro Abadia, O. \& González Morales, M. R. 2005. L'analogie et la représentation de l'art primitif à la fin du XIXe siècle. L'Anthropologie 109 (4): 703-21.
Reinach, S. 1903. L'art et la magie. À propos des peintures et des gravures de l'Âge du Renne. L'Anthropologie XIV: 257-66.

Richard, N. 1993. De l'art ludique à l'art magique. Interprétations de l'art pariétal au xix ${ }^{\mathrm{e}}$ siècle. Bulletin de la Société Préhistorique française 90 (1-2): 60-68.

White, R. 2001. Personal ornaments from the Grotte du Renne at Arcy-sur-Cure. Athena Review 2 (4): 41-46.

Yar, B. \& Dubois, P. 1996. Les structures d'habitat au Paléolithique inférieur et moyen en France : entre réalité et imaginaire. Bulletin de la Société Préhistorique française 93 (2): 149-63. 